\title{
Effects of marginal vegetation removal on Odonata communities
}

Efeitos da retirada da vegetação marginal sobre a comunidade de Odonata

\author{
Fernando Geraldo de Carvalho ${ }^{1}$, Nelson Silva Pinto ${ }^{2}$, \\ José Max Barbosa de Oliveira Júnior ${ }^{3}$ and Leandro Juen ${ }^{4}$
}

${ }^{1}$ Curso de Especialização em Perícia Ambiental, Pontífica Universidade Católica de Goiás - PUC Goiás, Av. Universitária, 1069, Área 4, Bloco A, Campus I, Setor Universitário, CEP 74605-010, Goiânia, GO, Brazil e-mail: nandocarvalho_g@hotmail.com

${ }^{2}$ Programa de Pós-graduação em Ecologia e Evolução, Departamento de Ecologia,

Universidade Federal de Goiás - UFG, CEP 74001-970, Goiânia, GO, Brazil e-mail: nelsonsilvapinto@gmail.com

${ }^{3}$ Programa de Pós-graduação em Ecologia e Conservação, Universidade do Estado do Mato Grosso - UNEMAT, CEP 78690-000, Nova Xavantina, MT, Brazil

e-mail: maxbio@hotmail.com

${ }^{4}$ Instituto de Ciências Biológicas, Universidade Federal do Pará - UFPA,

Rua Augusto Correia, 1, Bairro Guama, CEP 66075-110, Belém, PA, Brazil e-mail: leandrojuen@ufpa.br

\begin{abstract}
Aim: Here we assess the effects of habitat degradation on individuals of the two suborders of Odonata community of Borecaia river sub-basin. More specifically, we tested the hypothesis that Anisoptera richness would be positively affected by removal of vegetation; on the other hand, Zygoptera richness would be adversely affected by virtue of their ecophysiological requirements; Methods: We selected 10 streams of similar orders, six preserved and four degraded. Streams characterized as preserved had values of Index of Habitat Integrity (HII) above $0.70(0.77 \pm 0.07$, mean \pm SD) and continuous forest on both sides with a minimum width of 70 meters. Each site was sampled three times on different days. The effect of vegetation removal on richness was assessed using richness estimated by first order Jackknife; Results: Decreased physical integrity (measured with IIH) of streams had no significant effect on the estimated richness to Odonata in general. However, the estimated richness of Anisoptera showed an inverse relationship with the integrity $\left(r^{2}=0.485, P=0.025\right)$, i.e., there was a reduction in their species richness with increasing integrity; Discussion: As a general pattern, Anisoptera presents higher richness in an altered site; on the other hand, Zygoptera presents higher richness in a preserved one. This pattern suggests that Odonata needs to be considered at the sub-order level to access the effects of habitat degradation on these insects. Because of its restrictions ecophysiological Odonata varied widely in their composition and species richness between the two types of environments, it reinforces the potential of the order of studies and environmental monitoring also shows that Zygoptera be more affected by changes in habitat. However, further studies including more samples and different streams are need to confirm this pattern, being an interesting line of research for future works.
\end{abstract}

Keywords: environmental integrity, Anisoptera, Zygoptera, species richness, environmental changes.

Resumo: Objetivos: Com o intuito de avaliar os efeitos de mudanças na integridade ambiental sobre os indivíduos da comunidade de Odonata da sub-bacia do rio Borecaia, testamos a hipótese de que a riqueza de Anisoptera seria afetada positivamente pela remoção da vegetação; por outro lado, a riqueza Zygoptera seria prejudicada em virtude de suas necessidades ecofisiológicas; Métodos: Selecionamos 10 riachos de ordens similares, seis classificados como preservados e quatro como alterados. Riachos classificados como preservados apresentaram valores do Índice valores de Integridade Habitat (HII) acima de 0.70 e mata continua nas duas margens com uma largura mínima de 70 metros. Cada ponto foi amostrado três vezes em dias diferentes. O efeito de remoção de vegetaçáo sobre a riqueza foi avaliada utilizando Jackknife de primeira ordem; Resultados: A diminuição da integridade física (mensurada com o IIH) dos córregos náo exerceu efeito significativo sobre a riqueza estimada para a Ordem Odonata. Porém, a riqueza estimada de Anisoptera apresentou uma relação inversa com a integridade $\left(r^{2}=0.485 ; \mathrm{p}=0.025\right)$, mostrando que com o aumento da integridade houve uma redução na sua riqueza de espécies; 
Discussáo: Como um padrão geral, Anisoptera apresenta maiores valores de riqueza em locais alterados; por outro lado, Zygoptera apresenta maiores valores em preservados. Devido suas restriçóes ecofisiologicas Odonata apresentou uma grande variaçáo na sua composição e riqueza de espécie entre os dois tipos de ambientes, isso reforça o potencial da ordem em estudos de monitoramento ambiental e também mostra que Zygoptera será mais afetada pelas transformaçôes de habitat. No entanto, futuros estudos incluindo mais amostras e diferentes córregos são necessários para confirmar este padrão sendo uma linha de pesquisa interessante para trabalhos futuros.

Palavras-chave: integridade ambiental, Anisoptera, Zygoptera, riqueza de espécies, alterações na vegetação ripária.

\section{Introduction}

Deforestation may lead to rivers degradation resulting in increases on sedimentation levels, changes in hydrological cycles, and serious decreases in water quality due to chemical effluents (Callisto et al., 2001; Pond et al., 2008). The removal of riparian vegetation may contribute to these alterations, and has a direct effect in availability of organic matter and in the input of organic matter, primary source of energy in trophic chains of rivers (Lima and Zakia, 2001). In temperate rivers, deforestation has caused changes in macroinvertebrate assemblages, due to changes in light, temperature, nutrient levels, particle size substrate, distribution and availability of food resources (Bojsen and Jacobsen, 2003).

Odonata inhabits all kinds of freshwater environments, showing high diversity in the tropics. The species composition of Odonata assemblages can vary according to the modifications of certain environmental parameters, such as, the presence of marginal vegetation (Monteiro-Júnior et al. 2013), hydroperiod, pollutants, $\mathrm{pH}$, conductivity, dissolved oxygen, water temperature and water flow (Corbet, 1999).

Due to ecophysiological requirements regarding flight behavior and thermoregulation, the order Odonata can be divided into two groups: the 'perchers', which remain the most of the time perched on different types of substrate, making only shorts flies, between oviposition sites and foraging; and 'flyers', who remain on the wing in most of their period of activity (Corbet, 1962, 1999; May, 1976). The perchers are generally ectothermic, using directly or indirectly sunlight as the main source of heat. They can be thermal conformers or heliothermic. Thermal conformers present smaller body size and show higher conductance (high body heat exchange with the environment temperature) and body temperature varies with the environment, mainly due to heat exchange (De Marco Junior,
1998). This group is mainly composed by small zygopterian species, such species of genus Protoneura and Ischnura. Heliothermic have larger body size and consequently lower conductance, being their activities determined primarily by solar irradiation. This group is the most heterogeneous, because it includes Zygoptera and Anisoptera species. Furthermore, presents species of most representative Neotropical genus, e.g. Erythrodiplax, Hetaerina, some Gomphidae, etc. The flyers are endothermic, as they are able to produce heat by controlling the hemolymph's movement, flight and wing-whirring (Corbet and May, 2008). Endothermic group is composed only by large anisoptera (e.g. Aeshinidae and larger Libellulidae as these of Trameinni tribe).

The thermoregulatory strategies and ecophysiological patterns of Odonata may be associated with body size (Corbet, 1999; Corbet and May, 2008). These strategies should have an important role in dispersal capability, determining the energy expenditure and the flight capacity of the species (Corbet and May, 2008). The removal of vegetation can maximize the incidence of sunlight and alter the availability of food resources, which would lead to a process of homogenization of Odonata species, by replacement of estenotopic species by more generalist species (Remsburg and Turner, 2009). Thus, environmental changes (such as removal of riparian forest and marginal vegetation) would not influence in the same way the two Odonata suborders, because zygoptera (the small ones, thermal conformers) could be negatively affected by its ecological requirements (e.g., Loiola and De Marco 2011; Monteiro-Júnior et al., 2013); in the other hand anisoptera (and some larger zygoptera, e.g. Calopterygidae) could be positively affected, because these larger insects are adapted to environment with more light, excluding that more habitat-restricted ones (Ferreira-Peruquetti and De Marco Junior, 2002). 
Here we tested the hypothesis that Anisoptera richness in Borecaia river sub-basin would be positively affected by removal of riparian vegetation; while, Zygoptera richness would be adversely affected by virtue of their requirements.

\section{Material and Methods}

\subsection{Study area}

The sub-basin of Borecaia river (located between the coordinates: $13^{\circ} 56^{\prime} 30^{\prime \prime}$ to $14^{\circ} 12^{\prime} 30^{\prime \prime} \mathrm{S}$ and $51^{\circ} 42^{\prime} 30^{\prime \prime}$ to $51^{\circ} 51^{\prime} 30^{\prime \prime}$ W, Figure 1) is part of Mortes river basin in southwest of Mato Grosso state - MT (to the sample locations, abbreviations and accurate coordinates see Table 1). The climate of the region is tropical, with an average temperature of $24.67^{\circ} \mathrm{C}$, ranging annually from $16.7^{\circ} \mathrm{C}$ and $30.4{ }^{\circ} \mathrm{C}$. The area presents a distribution pattern typical of Cerrado biome, with two well defined seasons: a rainy season from October to March, with approximately $92 \%$ of total rainfall, and a dry period, which extends from April to September (Brasil, 1981).

\subsection{Sampling}

We selected 10 streams, six classified as preserved and four as altered (Figure 1). These sampling sites were selected based on the assessment of the Habitat Integrity Index (HII) (Nessimian et al., 2008). The HII index provides a quick method to evaluate the integrity of the system by quantifying

Table 1. Sample areas, abbreviations used on text and HII scores for each sample location. Scores values higher 0.7 indicates preserved areas (classified as preserved in this study).

\begin{tabular}{lcc}
\hline \multicolumn{1}{c}{ Sample areas } & Abbreviations & HII \\
\hline Matrichan stream & CRMT & 0.881 \\
Tritopá stream & CRT & 0.787 \\
Paca stream & CRP & 0.787 \\
Marayatobá stream & CRM & 0.731 \\
Areia Branca stream & CRAB & 0.706 \\
Água Limpa stream & CRAL & 0.706 \\
Estrela stream & CRE & 0.593 \\
Cigano stream & CRC & 0.325 \\
Boa Esperança stream & CRBE & 0.306 \\
Goiás stream & CRG & 0.262 \\
\hline
\end{tabular}

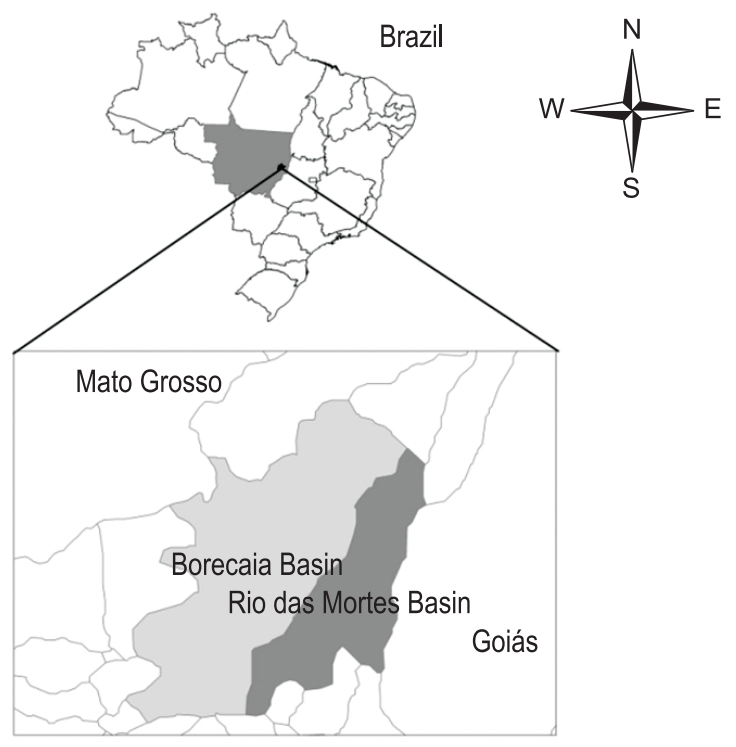

- $\quad$ Sampling points Hydrography Basin boundary

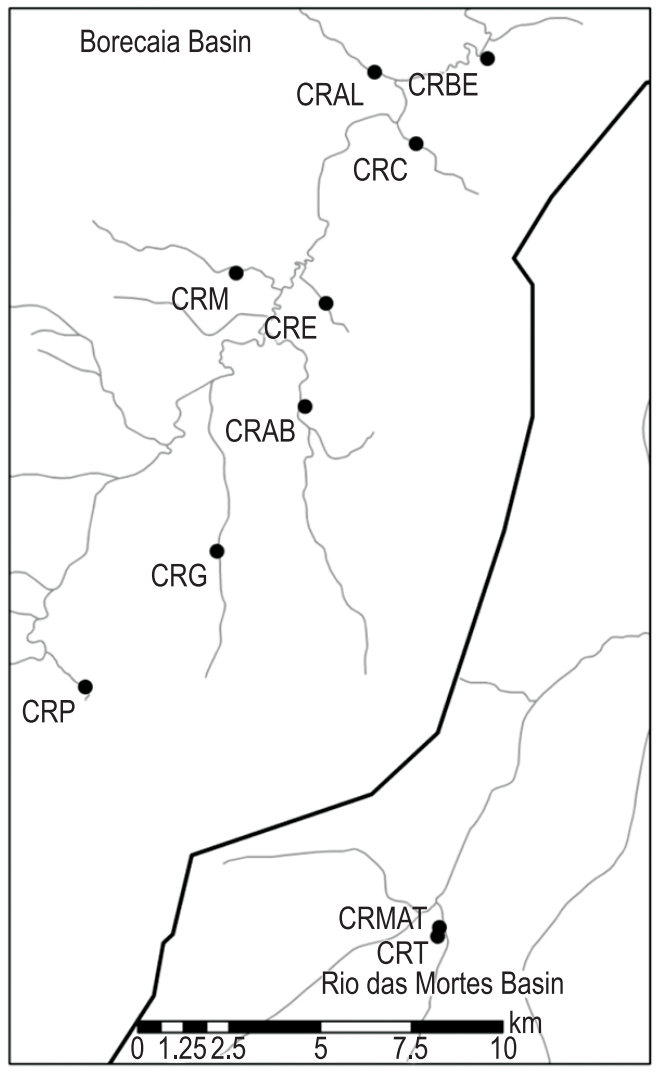

Figure 1. Study sites: 1a) Tritopá stream (CRT); 1b) Boa Esperança stream (CRBE); 1c) Marayatobá stream (CRMAT), Cigano stream (CRC), Água Limpa stream (CRAL); 1d) Areia Branca stream (CRAB), 1e) Paca stream (CRP), Estrela stream (CRE); and 1f) Matrichã stream (CRM), belonging to Borecaia river sub-basin, Nova Nazaré (MT). To classification status (altered or preserved) please refer to Table 1 (scores higher than 0.7 indicates preserved sites). 
the state of preservation of riparian forest; retention and sediment in river/stream channel; appearance of stone substrate; characteristics of river flow; and aquatic vegetation. These questions were implemented in all streams; values range from zero to one, and values closer to 1 indicate more natural areas. Additionally, we run a T-test of Student (Zar, 1999) between scores to preserved and degraded areas, in order to evaluate if significant differences exist.

The specimens were collected in the months of April to July 2010, in the dry season, from 9:00 AM to 3:00 PM, with temperatures above $19{ }^{\circ} \mathrm{C}$ and open sky, being these the minimum weather conditions in which these insects are active (Marco and Resende, 2002; May, 1976, 1991). Each point was sampled three times on different days. Sampling was based on the scanning method with fixed areas (De Marco Junior, 1998), already used in other studies (Reis et al., 2011; Juen and De Marco Junior, 2011; Silva-Pinto et al., 2012). For the identification of collected specimens at species level, systematic keys were used (Borror, 1945; Costa et al., 2002; Garrison et al., 2006; Heckman, 2006, 2008; Lencioni, 2006).

\subsection{Physical-chemical variables}

In each sampling site the mean width of the channel $(\mathrm{m})$ was measured at five equidistant points $(20 \mathrm{~m})$ along of transect, using a measuring tape of $50 \mathrm{~m}$. The mean depth of the channel (m) was calculated in the same locations, one in the center and one in each channel margin. The $\mathrm{pH}$ and conductivity $(\mu \mathrm{s} / \mathrm{cm})$ were determined with an electronic portable measurer (Aqua-CheckTM Water Analyzer Operator, O.I. Analytical). Dissolved oxygen $(\mathrm{mg} / \mathrm{L})$ and temperature $\left({ }^{\circ} \mathrm{C}\right)$ were determined with the portable oximeter/ thermometer (Yellow Springs Ints., model 58), and turbidity was obtained with turbidimeter (300 TD model Instrutherm).

\subsection{Statistical analysis}

Richness of observed species is often a biased estimative to species richness. Therefore, we use the non-parametric first order Jackknife resampling estimator (Coddington and Levi, 1991; Colwell and Coddington, 1994; Heltshe and Forrester, 1983), with EstimateS Win 7.5.0 software (Colwell, 2000). This method is able to estimate the total richness summing observed richness (number of species collected) to a parameter calculated from the number of rare species. This technique produces an approximate estimative of species richness in a community (Krebs, 1999), providing a confidence interval that allows the realization of comparisons between two or more regions sampled. These comparisons are made by confidence interval overlapping: when two or more confidence intervals are overlapping, they are no different.

To determine the relationship between richness/ abundance and integrity of streams (obtained by HII) simple linear regression analyses were carried out. This procedure is one of the most used, since it provides a simple functional relationship between the variables (linear) (Zar, 1999). All assumptions were tested, and when they were not satisfied, the data were log-transformed.

\section{Results}

\subsection{Community description}

The HII scores for preserved and altered sites is presented on Table 1. Preserved areas presented scores higher than 0.7. There was a significant difference in HII scores between preserved and altered areas $(\mathrm{t}$-test $=5.758$; d.f. $=8$; $\mathrm{p}<0.001)$. The most representative species in altered sites were Erythrodiplax basalis (Kirby, 1897) (142 individuals), Diastatops obscura (Fabricius, 1775) (37 individuals) and Erythemis credula (Hagen 1861 (12 individuals)). Already by preserved sites were Hetaerina curvicauda Garrison, 1990 (42 individuals), Argia reclusa Selys, 1865 (36 individuals), Acanthagrion apicale Selys, 1876 (19 individuals) and Hetaerina rosea Selys, 1853 (19 individuals) Table 2.

The total richness of Odonata order was evaluated based on inference by confidence interval technique. The greatest richness was observed in the CRG site with 35.78 species $( \pm 7.46)$ (mean \pm confidence interval), showing 10 species more than CRAB site $(25.88 \pm 4.94)$, which was the second most diverse, and was followed by CRC $(9.93 \pm 3.84)$ and CRAL sites $(10.97 \pm 2.76)$, which presented ten species less than CRAB. In other places, richness was not different, because the confidence intervals of a group overlapped the average of other (Figure 2).

Using the same technique, we can see that for Anisoptera, the site with the greatest richness was CRG, with $22.87( \pm 5.22)$ estimated species, showing 10 species more than CRAB and CRC. CRBE and CRMT presented five species less than CRAB and CRC. The sites CRAL, CRE, CRM, CRT and CRP had lower richness (Figure 3a). 
Table 2. Abundance of odonates in degraded and preserved streams in Nova Nazaré municipality, Mato Grosso, Brazil.

\begin{tabular}{|c|c|c|c|c|c|}
\hline Suborder & Family & Species & Degraded & Preserved & Total \\
\hline Anisoptera & Libellulidae & Diastatops intensa & 3 & 1 & 4 \\
\hline Anisoptera & Libellulidae & Diastatops obscura & 37 & 1 & 38 \\
\hline Anisoptera & Libellulidae & Erythemis credula & 12 & 0 & 12 \\
\hline Anisoptera & Libellulidae & Erythrodiplas paraguayensis & 2 & 0 & 2 \\
\hline Anisoptera & Libellulidae & Erythrodiplax amazonica & 0 & 1 & 1 \\
\hline Anisoptera & Libellulidae & Erythrodiplax amazonica melanica & 0 & 1 & 1 \\
\hline Anisoptera & Libellulidae & Erythrodiplax basalis & 142 & 19 & 161 \\
\hline Anisoptera & Libellulidae & Erythrodiplax basalis avittata & 0 & 1 & 1 \\
\hline Anisoptera & Libellulidae & Erythrodiplax fusca & 2 & 5 & 7 \\
\hline Anisoptera & Libellulidae & Erythrodiplax juliana & 1 & 0 & 1 \\
\hline Anisoptera & Libellulidae & Erythrodiplax maculosa & 5 & 0 & 5 \\
\hline Anisoptera & Libellulidae & Erythrodiplax paraguayensis & 7 & 0 & 7 \\
\hline Anisoptera & Libellulidae & Erythrodiplax umbrata & 3 & 1 & 4 \\
\hline Anisoptera & Libellulidae & Fylgia amazonica & 0 & 18 & 18 \\
\hline Anisoptera & Libellulidae & Gynothemis sp. & 0 & 3 & 3 \\
\hline Anisoptera & Libellulidae & Macrothemis sp. & 0 & 1 & 1 \\
\hline Anisoptera & Libellulidae & Miathyria marcella & 6 & 0 & 6 \\
\hline Anisoptera & Libellulidae & Micrathyria spuria & 1 & 0 & 1 \\
\hline Anisoptera & Libellulidae & Micrathyria stawiarskii & 1 & 0 & 1 \\
\hline Anisoptera & Libellulidae & Nephepeltia phryne & 1 & 0 & 1 \\
\hline Anisoptera & Libellulidae & Oligoclada abbreviata limnophila & 1 & 0 & 1 \\
\hline Anisoptera & Libellulidae & Oligoclada limnophila & 1 & 1 & 2 \\
\hline Anisoptera & Libellulidae & Oligoclada pachystigma & 0 & 1 & 1 \\
\hline Anisoptera & Libellulidae & Oligoclada walkeri & 0 & 1 & 1 \\
\hline Anisoptera & Libellulidae & Oligoclada xanthopleura & 3 & 0 & 3 \\
\hline Anisoptera & Libellulidae & Orthemis ambirufa & 0 & 1 & 1 \\
\hline Anisoptera & Libellulidae & Orthemis discolor & 7 & 0 & 7 \\
\hline Anisoptera & Libellulidae & Orthemis sp. & 1 & 0 & 1 \\
\hline Anisoptera & Libellulidae & Perithemis lais & 0 & 16 & 16 \\
\hline Anisoptera & Libellulidae & Planiplax sp & 1 & 0 & 1 \\
\hline Anisoptera & Libellulidae & Uracis reducta & 0 & 4 & 4 \\
\hline Anisoptera & Libellulidae & Zenithoptera viola & 1 & 0 & 1 \\
\hline Zygoptera & Coenagrionidae & Acanthagrion apicale & 2 & 19 & 21 \\
\hline Zygoptera & Coenagrionidae & Acanthagrion ascendens & 1 & 9 & 10 \\
\hline Zygoptera & Coenagrionidae & Acanthagrion jessei & 11 & 3 & 14 \\
\hline Zygoptera & Coenagrionidae & Acanthagrion sp1 & 5 & 0 & 5 \\
\hline Zygoptera & Coenagrionidae & Aeolagrion flammeum & 0 & 5 & 5 \\
\hline Zygoptera & Coenagrionidae & Argia mollis & 0 & 15 & 15 \\
\hline Zygoptera & Coenagrionidae & Argia reclusa & 1 & 36 & 37 \\
\hline Zygoptera & Protoneuridae & Epipleoneura machadoi & 2 & 12 & 14 \\
\hline Zygoptera & Protoneuridae & Epipleoneura metallica & 0 & 11 & 11 \\
\hline Zygoptera & Coenagrionidae & Helveciagrion obsoletum & 0 & 1 & 1 \\
\hline Zygoptera & Calopterygidae & Hetaerina auripennis & 0 & 5 & 5 \\
\hline Zygoptera & Calopterygidae & Hetaerina curvicauda & 1 & 42 & 43 \\
\hline Zygoptera & Calopterygidae & Hetaerina laesa & 0 & 1 & 1 \\
\hline Zygoptera & Calopterygidae & Hetaerina rosea & 1 & 19 & 20 \\
\hline Zygoptera & Coenagrionidae & Ischnura capreolus & 1 & 0 & 1 \\
\hline Zygoptera & Calopterygidae & Mnesarete lencioni & 0 & 2 & 2 \\
\hline Zygoptera & Calopterygidae & Mnesarete williamsoni & 0 & 1 & 1 \\
\hline Zygoptera & Protoneuridae & Neoneura sylvatica & 0 & 8 & 8 \\
\hline Zygoptera & Protoneuridae & Peristicta aenoviridis & 0 & 5 & 5 \\
\hline Zygoptera & Protoneuridae & Protoneura tenuis & 0 & 1 & 1 \\
\hline Zygoptera & Coenagrionidae & Tigriagrion aurantinigrum & 6 & 11 & 17 \\
\hline
\end{tabular}


For Zygoptera, sites with greater estimated species richness were $\mathrm{CRAB}$ with $12.97( \pm 2.76)$ and $\mathrm{CRG}$ $10.93( \pm 3.84)$, and there was no difference among the other sites based on the confidence intervals overlap (Figure 3b).

\subsection{Species richness between environments with different degrees of conservation}

When we analyze all species richness (Anisoptera and Zygoptera) there was no difference between preserved and altered sites (Figure 4), based on confidence intervals. However, when we carried out the estimate of species richness separated by suborders (Zygoptera or Anisoptera), for both

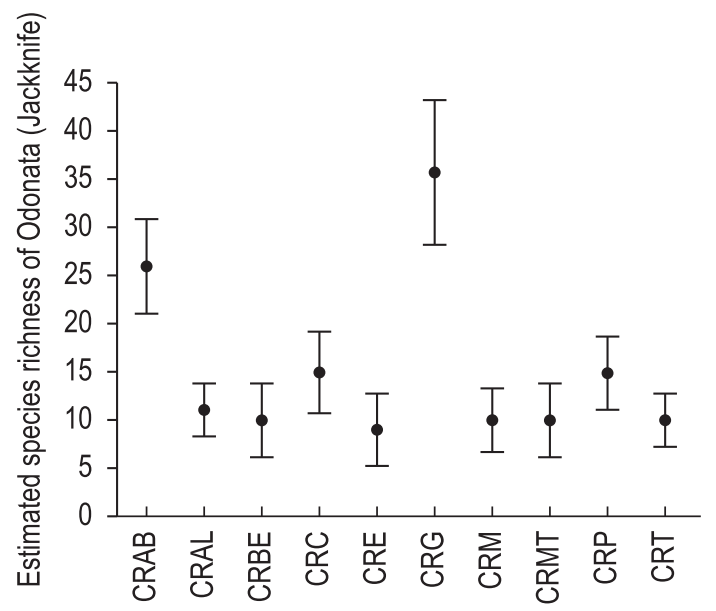

Figure 2. Estimated species richness of Odonata by Jackknife procedure, in the Cerrado streams of Nova Nazaré (MT), distributed according to sampled sites in 2010. Bars represent confidence interval of $95 \%$. To classification status (altered or preserved) please refer to Table 1 (scores higher than 0.7 indicates preserved areas).
Anisoptera and Zygoptera there were differences in species richness (Figure 5).

For Anisoptera in degraded areas the number of estimated species was $34.93( \pm 7.74)$, presenting 15 species more than in the preserved areas (Figure 5a). For Zygoptera, we observed the opposite; in preserved sites the estimated number of species was $22.99( \pm 4.83)$, presenting eight species more than degraded sites (Figure 5b). However, the estimated richness of Anisoptera decreases with increased integrity $\left(r^{2}=0.485 ; p=0.025\right.$; Figure 6).

\section{Discussion}

The physical classification by HII shows differences in habitat quality between disturbed and preserved sites. Observed patterns in Odonata shows that biological assessment of this area reflects the physical evaluation, suggesting that HII is a good complementary tool in Cerrado streams. Previous studies showed similar results (Nogueira et al., 2011; Shimano et al., 2010; Reis et al., 2011) although the HII has been developed to evaluate characteristics of Amazonian streamlets (Nessimian et al., 2008).

As a general pattern there is no Odonata richness difference between altered and preserved sites, except for CRG (altered) and CRAB (preserved) that presented the highest richness observed. However, when analyzed separately, Anisoptera presents higher richness in altered sites, while Zygoptera presents higher richness in preserved sites. This pattern, although it should be considered with caution, due to the reduced number of study sites, suggests that Odonata need to be considered at the sub-order level to access effects of environmental changes on these insects (Monteiro-Júnior et al., 2013). These authors discusses that, when the two
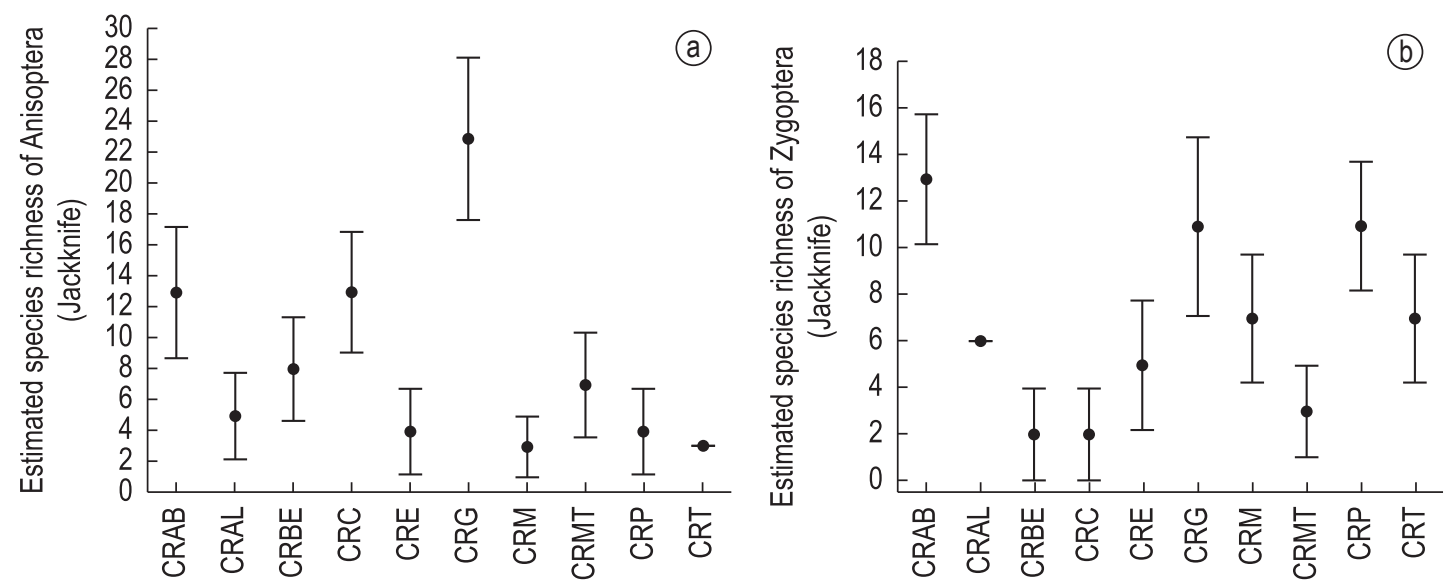

Figure 3. Estimated species richness by Jackknife procedure, in the Cerrado streams of Nova Nazaré (MT), 2010. a) Anisoptera and b) Zygoptera. Bars represent confidence interval of 95\%. To classification status (altered or preserved) please refer to Table 1 (scores higher than 0.7 indicates preserved areas). 


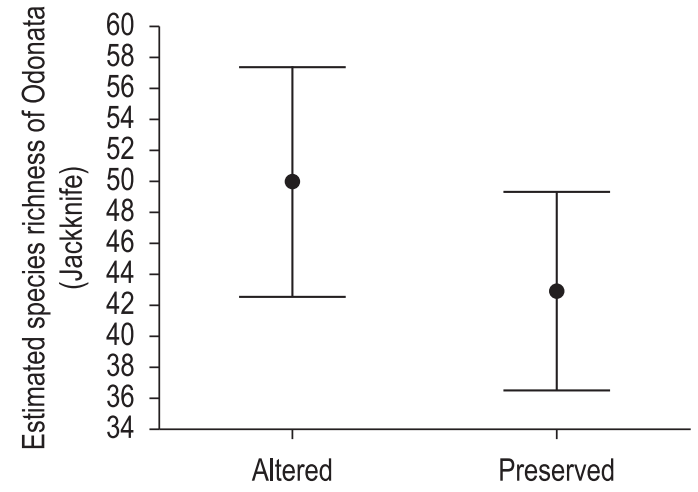

Figure 4. Estimated species richness of Odonata by Jackknife procedure, in the Cerrado streams of Nova Nazaré (MT), distributed according to conservation level, 2010. Bars represent confidence interval of $95 \%$. To classification status (altered or preserved) please refer to Table 1 (scores higher than 0.7 indicates preserved areas). infra-orders are considered together, direct effects of environmental alteration by human activities on species richness may be confused, causing misinterpretations of some processes and patterns. Dias-Silva et al. (2010) suggests the same pattern to Heteroptera community that suffers similar effects. Here we suggest that, in further studies, this pattern may be evaluated in others aspects and considering other types of degradation.

In the areas classified as altered we have collected most of generalist species, e.g. Erythrodiplax fusca, Diastatops intensa and Hetaerina rosea. In a study with similar anthropogenic effects, FerreiraPeruquetti and De Marco Júnior (2002) have showed that some typical lentic species (e.g Ischnura fluviatilis and Erythrodiplax fusca) have increased their abundances, in consequence of deforestation and changes in water flow.
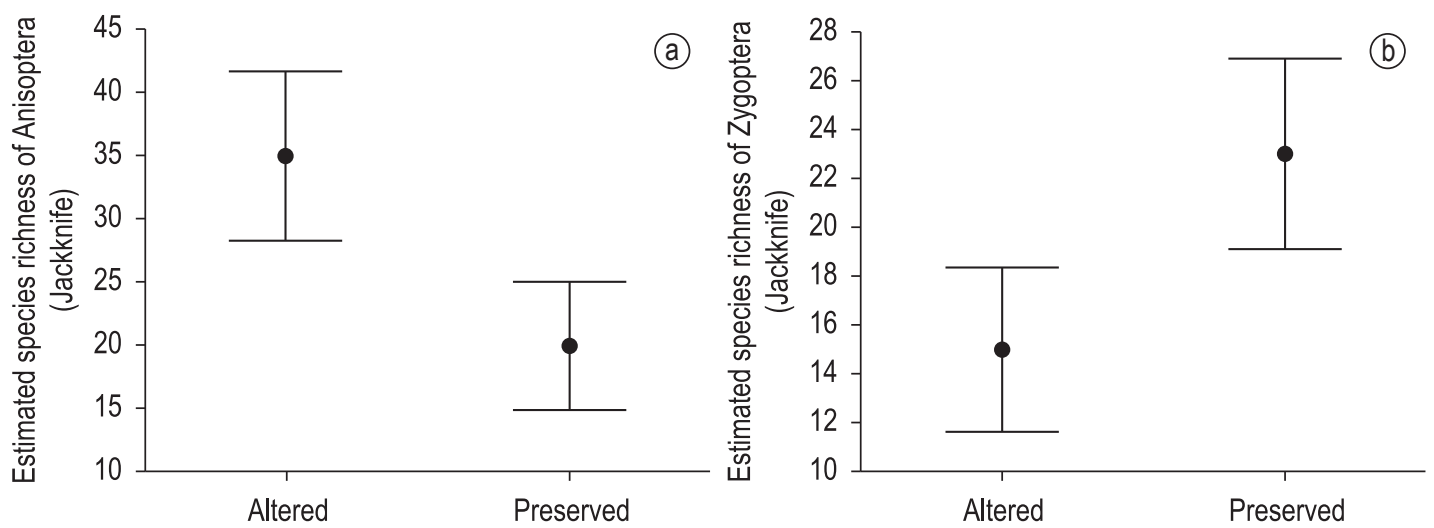

Figure 5. Estimated species richness of a) Anisoptera and b) Zygoptera by Jackknife procedure, in the Cerrado streams of Nova Nazaré (MT), distributed according to conservation level, 2010. Bars represent confidence interval of $95 \%$. To classification status (altered or preserved) please refer to Table 1 (scores higher than 0.7 indicates preserved areas).

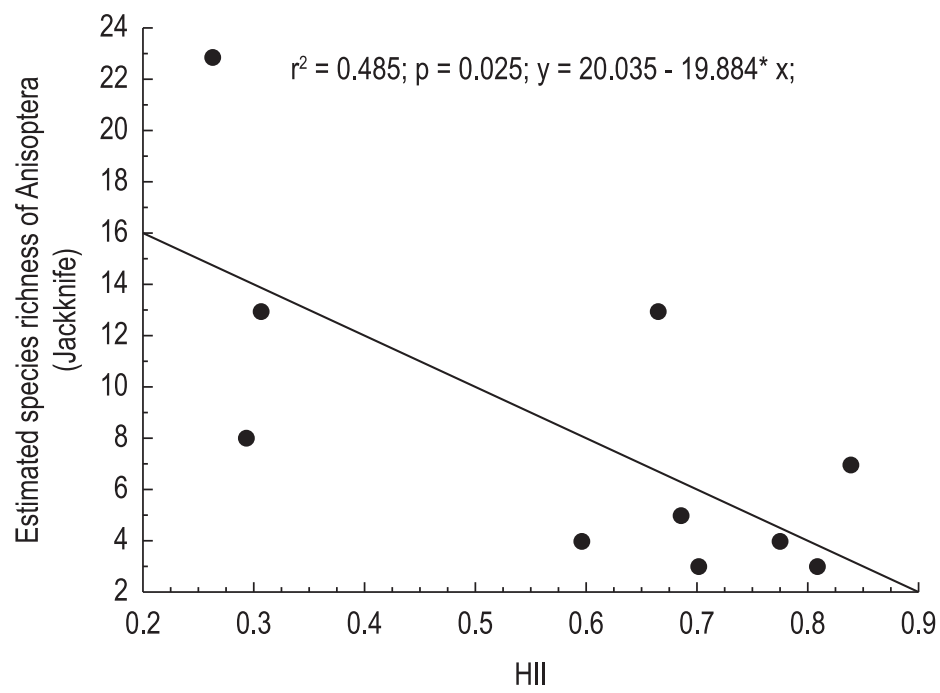

Figure 6. Relationship between estimated species richness of Anisoptera and Habitat Integrity Index (HII), sampled in Cerrado streams of Nova Nazaré (MT), 2010. 
Heteragrion consors populations studied by Loiola and De Marco (2008) showed a strongly dependency to shade locals, occurring into forest, maybe relative to its capacity to exchange heat by convection. As in our study sites, the Zygoptera species observed presents the same behavior. It is possible that, with removal of riparian vegetation and an intense increase in luminosity, and strongly variation in daily temperature may exclude some small zygopterian species. On the other hand medium to large sized Zygoptera and Anisoptera may be benefited and exclude those specialists by competition.

Odonata thermoregulatory theory suggests a "continuum" between two extremes: perchers and fliers (Corbet and May 2008). Fliers present larger sizes, and can produce endogenic heat. In this way, it is expected that fliers use entire landscapes, and not necessarily only the sites where they have been collected or observed. On the other extreme, the perchers, small sized ones, mainly composed by Zygoptera species, thermoregulate by convection, and can be affected by higher temperatures. Chang et al. (2007) have demonstrated that higher temperatures are associated with disruption in development, resulting in increases in mortality of zygopterian larvae. So, we expected this group to be the the first to be excluded on areas affected by riparian vegetation removal. The group that could be more benefited is that between these two extremes. This group is composed by Anisoptera and Zygoptera species, and is relatively resistant to these observed effects. They, probably have the most large temperature niche, and, although they could present some dependency of microhabitats to breeding (e.g. Guillermo-Ferreira and Del-Claro, 2012).

\section{Acknowledgements}

NSP is grateful to CAPES. The authors are grateful to the Dr. Fábio M. V. Carvalho and MSc. Yulie Shimano for support in translation, and to Caroline Costa Correa for help in preparing of map.

\section{References}

BOJSEN, BH. and JACOBSEN, D. 2003. Effects of deforestation on macroinvertebrate diversity and assemblage structure in Ecuadorian Amazonian streams. Archiv für Hydrobiologie, vol. 158, p. 317-342. http://dx.doi.org/10.1127/00039136/2003/0158-0317

BORROR, DJ. 1945. A Key to the new world genera of Libellulidae (Odonata), Annals of Entomological society of America, vol. 38, p. 188-194.
BRASIL. Ministério das Minas e Energia. Secretária Geral. Projeto RADAMBRASIL. 1981. Goiás: geologia, geomorfologia, pedologia, vegetação, uso potencial da terra. Rio de Janeiro: Ministério das Minas de Energia. Folha SD 22.

CALLISTO, M., MORETTI, M. and GOULART, M. 2001. Macroinvertebrados bentônicos como ferramenta para avaliar a saúde de riachos. Revista Brasileira de Recursos Hidricos, vol. 6, p. 71-82.

CODDINGTON, JA. and LEVI, HW. 1991. Systematics and Evolution of Spiders (Araneae). Annual Review of Ecology and Systematics, vol. 22, p. 565-592. http:// dx.doi.org/10.1146/annurev.es.22.110191.003025

COLWELL, RK. and CODDINGTON, JA. 1994. Estimating terrestrial biodiversity through extrapolation. Philosophical Transactions of the Royal Society of London, vol. 345, p. 101-118. http://dx.doi. org/10.1098/rstb.1994.0091

COLWELL, RK. 2000. EstimateS: statistical estimations of species richness and shared species from samples. version 6.0b1. Available from: <http://viceroy.eeb. uconn.edu/estimates>. Access in: 05 jan. 2009.

CORBET, PS. 1962. A Biology of Dragonflies. London: Witherby. $396 \mathrm{p}$.

CORBET, PS. 1999. Dragonflies: Behavior and Ecology of Odonata. New York: Comstock Publ. Assoc.

CORBET, PS. and MAY, ML. 2008. Fliers and perchers among odonata: dichotomy or multidimensional continuum? A provisional reappraisal the flier/percher template. International Journal of Odonatology, vol. 11, p. 155-17. http://dx.doi.org/10.1080/1388 7890.2008.9748320

COSTA, JM., LOURENÇO AN. and VIERA, LP. 2002. Chave de identificação para imagos dos gêneros de Libellulidae citados para o Brasil - Comentários sobre os gêneros (Odonata: Anisoptera). Entomología $Y$ Vectores, vol. 9, p. 477-504.

CHANG, X., ZHAI, B., LIU, X. and WANG, M. 2007. Effects of temperature stress and pesticide exposure on fluctuating asymmetry and mortality of Copera annulata (selys) (Odonata: Zygoptera) larvae. Ecotoxicology and Environmental Safety, vol. 67, p. 120-127. http://dx.doi.org/10.1016/j. ecoenv.2006.04.004

DE MARCO JUNIOR, P. 1998. The amazonian campina dragonfly assemblage: patterns in microhabitat use and behavior in a foraging habitat (Anisoptera). Odonatologica, vol. 27, p. 239-248.

DIAS-SILVA, K., CABETTE, HS. and JUEN, L. 2010. The influence of habitat integrity and physicalchemical water variables on the structure of aquatic and semi-aquatic Heteroptera. Zoologia vol. 27, no. 6, p. 918-930.

FERREIRA-PERUQUETTI, PS. and DE MARCO JUNIOR, P. 2002. Efeito da alteraçáo ambiental sobre a comunidade de Odonata em riachos de Mata 
Atlântica de Minas Gerais, Brasil. Revista Brasileira de Zoologia, vol. 19, p. 317-327. http://dx.doi. org/10.1590/S0101-81752002000200002

GARRISON, RW., VON ELLENRIEDER, N. and LOUTON, JA. 2006. Dragonfly Genera of the New World. Baltimore: Johns Hopkins University Press.

GUILLERMO-FERREIRA, R. and DEL-CLARO, K. 2011. Resource defense polygyny by Hetaerina rosea Selys (Odonata: Calopterygidae): influence of age and wing pigmentation. Neotropical Entomology, vol. 40, no. 1, p. 78-84. http://dx.doi.org/10.1590/ S1519-566X2011000100011

HELTSHE, J. and FORRESTER, N. 1983. Estimating species richness using the jackknife procedure. Biometrics, vol. 39, p. 1-11. http://dx.doi. org/10.2307/2530802

HECKMAN, CW. 2006. Encyclopedia of South American Aquatic Insects: Odonata-Anisoptera. Springer Science. p 793.

HECKMAN, CW. 2008. Encyclopedia of South American Aquatic Insects: Odonata-Zygoptera. Springer Science. p. 692.

JUEN, L. and DE MARCO JUNIOR, P. 2011. Odonate biodiversity in terra-firme forest streamlets in Central Amazonia: on the relative effects of neutral and niche drivers at small geographical extents. Insect Conservation and Diversity, vol. 4, p. 1-10. http:// dx.doi.org/10.1111/j.1752-4598.2010.00130.x

KREBS, CJ. 1999. Ecological Methodology. Columbia: University of British. 620 p.

LENCIONI, FAA. 2006. Damelflies of Brazil, an illustrated indentification guideII: Coenagrionidae families. São Paulo: All Print Editora.

LIMA, WP. and ZAKIA, MJB. 2001. Hidrobiologia das matas ciliares. In RODRIGUES, RR. and LEITÁOFILHO, HF., eds. Matas ciliares: conservação e recuperação. São Paulo: Editora Universidade de São Paulo, FAPESP. p. 33-44.

LOIOLA, G. R. and DE MARCO, P. 2011. Behavioral ecology of Heteragrion consors Hagen (Odonata, Megapodagrionidae): a shade-seek Atlantic forest damselfly. Revista Brasileira de Entomologia, vol. 55, p. 373-380. http://dx.doi.org/10.1590/S008556262011005000036

MAY, ML. 1976. Energy metabolism of dragonflies (Odonata: Anisoptera) at rest and during endothermic warm-up. Journal of Experimental Biology, vol. 83, p. 79-94.

MAY, ML. 1991. Thermal adaptation of dragonflies, revisited. Advances in Odonatology, vol. 5, p. 71-88.
MONTEIRO-JÚNIOR, CS., COUCEIRO, SRM., HAMADA, N. and JUEN, L. 2013. Effect of vegetation removal for road building on richness and composition of Odonata communities in Amazonia, Brazil. International Journal of Odonatology, vol. 17, p. 1-13. http://dx.doi.org/10.1080/13887890.201 3.764798

NESSIMIAN, JL., VENTICINQUE, E., ZUANON, J., DE MARCO JUNIOR, P., GORDO, M., FIDELIS, L., BATISTA, JD., JUEN, L. 2008. Land use, habitat integrity, and aquatic insect assemblages in Central Amazonian streams. Hydrobiologia, vol. 614, p. $117-$ 131. http://dx.doi.org/10.1007/s10750-008-9441-x

NOGUEIRA, DS., CABETTE, HSR. and JUEN, L. 2011. Estrutura e composição da comunidade de Trichoptera (insecta) de rios e áreas alagadas da bacia do rio Suiá-Miçú, Mato Grosso, Brasil. Iheringia, Série Zoologia, vol. 101, no. 3, p. 173-180. http:// dx.doi.org/10.1590/S0073-47212011000200004

POND, GJ., PASSMORE, ME., BORSUK, FA. and REYNOLDS, L. 2008. Downstream effects of mountaintop coal mining: comparing biological conditions using family-and genus-level macroinvertebrate bioassessment tools. Journal of the North American Benthological Society, vol. 27, p. 717 737. http://dx.doi.org/10.1899/08-015.1

SILVA-PINTO, N., JUEN, L., CABETTE, HSR. and MARCO, P. 2012. Fluctuating Asymmetry and Wing Size of Argia tinctipennis Selys (Zygoptera: Coenagrionidae) in Relation to Riparian Forest Preservation Status. Neotropical Entomology, vol. 41, no. 3, p. 178-185. http://dx.doi.org/10.1007/ s13744-012-0029-9

REIS, EF., PINTO, NS., CARVALHO, FG. and JUEN, L. 2011. Efeito da integridade ambiental sobre a assimetria flutuante em Erythrodiplax basalis (Libellulidae: Odonata) (Kirby). Entomobrasilis, vol. 4, no. 3, p. 103-107.

REMSBURG, AJ. and TURNER, MG. 2009. Aquatic and terrestrial drivers of dragonfly (Odonata) assemblages within and among north-temperate lakes. Journal of the North American Benthological Society, vol. 28, p. 44-56. http://dx.doi.org/10.1899/08004.1

SHIMANO, Y., CABETTE, HSR., SALLES, FF. and JUEN, L. 2010. Composição e distribuição da fauna de Ephemeroptera (Insecta) em área de transiçáo Cerrado-Amazônia, Brasil. Iheringia, vol. 100, p. 301-308. http://dx.doi.org/10.1590/S007347212010000400004

ZAR, JH. 1999. Biostatistical analysis. 4th ed. Englewood Cliffs: Prentice-Hall. 